\title{
Theoretical reflections on the life world of Tanzanian street
}

\section{children}

By Markus Wiencke (Free University, Berlin)

In this article I reconstruct the life world (Lebenswelt) of the street children of the Tanzanian city Mwanza from an emic perspective that emphasises meaning-making, in order to depict them as subjects solely responsible for their actions. Accordingly I shall present how two youths conveyed to me, in numerous colour drawings, their everyday urban life, which is associated with their village history. Furthermore I will present some theoretical reflections on the "life world": I will explore the life world of the children and youths with reference to the construction and formation of identity. It thus becomes clear that even violent and materially difficult living conditions can generate collective identities. The term "street children", which is generally perceived as derogatory, receives a more positive connotation in this way. This is deepened by the description of the street children's relationships, which alternate between solidarity and conflict.

\section{Introduction}

According to Article 1 of the UN Convention on the Rights of the Child, "a child means every human being below the age of eighteen years" (http://www2.ohchr.org/english/law/crc.htm). From a socio-historical perspective, however, childhood is not only a certain biological age, encompassing the period of life from birth to puberty, but particularly a societal and era-related concept (Alber 2002:91-92). As a societal construct, childhood cannot be separated from other societal aspects such as ethnicity, rank, and gender, and it is embedded in a social and historical context (James and Prout 1997). Current ethnographic studies of childhood focus on researching everyday life. But although an attempt is made to depict children's everyday life as authentically and as free from the influence of adults as possible, during this process normative classification criteria are inevitably being used which are expressions of a certain image researchers have of successful childhood, and which thus should be questioned (Honig, Leu and Nissen 1996).

I reconstruct the life world of the street children of Mwanza - the second biggest city in Tanzania - from an emic perspective that emphasises meaning-making, in order to depict my informants as subjects solely responsible for their actions (Wiencke 2007a). Mwanza, the capital of the region Mwanza, is situated in the northwest of Tanzania, sitting directly on the shores of Lake Victoria. It is one of the most densely populated regions of the country and characterised by wide plains, which are interrupted by hills and rock formations. Local government has detected a large increase in population over the last ten years, rising from 223,000 people in 1990 to 512,000 people in 1999 (Van Gogh 2000:20). These numbers are not exact, but they do emphasise Mwanza's importance in terms of rural migration from the western parts of the country to the 
city. Mwanza plays an important role in international trade, being a location of commerce for Uganda, Kenya, Rwanda, Democratic Republic of Congo, and Tanzania. Many people live on the shores of Lake Victoria, making a living out of fishing. And a great number of companies there have specialised in processing and trading fish. The city's actual expanse is fairly large, although the city centre, with its shops and offices, is quite small.

During fieldwork, I aimed to obtain close impressions and gain insights into the lives of my informants by means of ethnographic and problem-centred interviewing methods, drawings, and by the use of participant-observation (Spradley 1979, 1980; Witzel 1989). The data thus obtained was subsequently analysed using content analysis (Mayring 2003). Following Geertz's example (1999:24), I obtained "thick descriptions" of the life world of street children in Mwanza. Wolff (2000:339-340) points out that research is always an intervention into a social system. According to this understanding, I represented a disturbing factor to the street children. A question of validity remains as to what extent my constructions originate in the constructions of the researched, and to what extent this origin is comprehensible to others. I therefore made the research process as comprehensible to others as possible by providing detailed documentation (cf. Matt 2003). Specific sources of variability included how I presented myself, the establishing of relationships with my interviewees - including gender role ascriptions - as well as the specific interview situations (Denzin 1989:113-118).

First, I will set the scene by illustrating to what extent globalisation processes in Tanzania influence moral concepts and social structures of local communities. I will then demonstrate why the term "street child" is problematic, and will present how two youths conveyed to me, in numerous colour drawings, their everyday urban life, which is associated with their village history. The use of drawings as a research method is an interesting and innovative approach, and should be considered more often in researching street children (cf. Belo 1970). Then I will explore the life world of the children with reference to the construction and formation of identity. It thus becomes clear that even violent and materially difficult living conditions can generate collective identities (Luig 2007, cf. Scheper-Hughes and Hoffman 1998, for Brazilian street children). The criteria to define the "typical street child" are numerous. A street child spends the majority of the day on the street and in some cases the night as well. "Street" refers here to all public and social spaces that are either accessible to street children or made accessible by them. Family ties are either entirely broken or tenuous, and if the child is still in touch with her/his family the legal guardian is no longer the psychological parent. The street is the child's most important field of being, and it is there that she/he is mainly shaped. Most activities of everyday life such as working, playing, eating, sleeping or maintaining social relations occur here without the child having any kind of special protection or care (Dachtler 1999:21-22). When the term "street children" is used in the following it includes adolescents since many 20 -year olds still live on the street in a very similar way to the younger ones. I will conclude by summarising an update of the past three years and a general discussion of my results.

\section{Deconstruction of the concept "street child"}

Only some of the children who spend time on the street are actually "street children". In academic literature a distinction is therefore made between children who live on the 
street ("children of the street") and those who earn money on the street for themselves and/or their families ("children on the street") (Donald and Swart-Kruger 1994:169). Richter (1988:1) defines street children, the "children of the street", as children who "have abandoned (or have been abandoned by) their families, schools and immediate communities, before they are sixteen years of age, and [have] drifted into a nomadic street life". According to Glauser (1997) this definition is problematic in that children may alternate between a life on the street and temporary periods at relatives' and/or friends' places, or in welfare institutions or in prison. Therefore, it appears reasonable to assume that there is a continuum between the two groups, with the categorisation of any given individual to be determined by her/his circumstances (Aptekar and Abebe 1997:480).

"Street child" itself is a problematic term because it hints at the negative aspects of such children's lives, such as their delinquency and the violence they encounter. It contains the moral implication of the streets as a place of illegal and criminal activity. In this sense, it is a remote and destructive term that only stresses the urgency in helping these children for whom the streets are necessary for survival. Furthermore, it contributes to an exclusively negative sense of identity for the child without a family, home, or school to attend (Liebel 1993, cf. Glauser 1997).

Schibotto (1993) suggests that the constructive activities of these children should be emphasised and that their subjective capacities should be demonstrated especially through work. In this respect, work involves all activities that are necessary for urban survival - independent from an official position - just as the rest of society understands the need for a salary as survival. Taking this into consideration, these children are essentially "working children" with a lot of experience concerning the freedom of autonomy and inventing ways to overcome daily struggles. Using the concept of "working children" (Schibotto 1993:134) helps to avoid moral reprobation and emphasises instead the socio-economic mechanisms responsible for the occurrence of this phenomenon. It thus becomes easier to lay a foundation for the construction of a more positive identity. The concept emphasises that different concepts of life are tried out in a positive way - including on the street - instead of focussing on the victim status associated with "street children". Unlike the metaphor "being on the street", associated with parasitic hanging around, "working on the street" (ibid:134-135) illustrates that the children make an important contribution to society and fulfil a social function. Being untrained, immediately available and cheap labour, they are also important for the labour market.

For the street children in question, their environment plays a crucial role in the development of identity and self-image. Thanks to Luig and Seebode (2003), we can call the street a learning place. These are places where young people take responsibility for themselves and generate needed income through both formal and informal methods. This term underlines the meaning of learning as the acquisition of social capital, which especially serves young people who are not in legally protected situations with better chances for survival and education (ibid:19-20).

\section{Stories and drawings}

During the first days of my stay in Mwanza, two male street children (19 and 22 years old) approached me to sell some postcards. These two and one other street boy (19 years old) came to play a particular role in my fieldwork. Together we went on many 
excursions in Mwanza and its surroundings. It was through them that I was able to establish most of the contacts to further street children. In my view, they hold a key position among the street children in Mwanza due to their long experience on the street. This is also demonstrated in the 22 qualitative interviews which were arranged and translated by one of them. The interviews were conducted in August and September 2001. The street children interviewed were between 13 and 22 years old. Seven of them were female, and 15 were male. From these interviews I obtained the majority of my information on the life world of street children in Mwanza.

I asked the two postcard artists to draw their biographies and the everyday life situations of a street child in Mwanza. In doing so, I did not further specify my request but instead let the youths themselves decide what they considered relevant. Both were paid for the pictures. After the pictures were completed, we talked about them. From over one hundred pictures produced by Sengondo (22) and Masumbuko (19), (these are pseudonyms and their real signatures have been removed from the drawings), this paper presents a concise selection of their work in order to give insights into their worlds. Two of the village pictures below (images 3 and 4) were drawn by Masumbuko, and the other seven pictures were drawn by Sengondo. Except for the picture "Street Kids", I provided the titles for the pictures. In the following section I will present my interpretation of each picture and subsequently provide complementary information from the interviews.

\section{(i) village pictures}

Sengondo has drawn many village pictures depicting a very happy, idealised way of life with everyone having enough to eat. These are ideals - wishes of how life ought to be. In the picture below, the people illustrated are carrying out their everyday tasks, strictly separated by gender. The men for example are tending to the animals or chopping wood, whilst the women are going about domestic activities or looking after small children. What initially seems to be a functional community, with all having enough to eat and all being provided with jobs, turns out be a lonely existence in parallel worlds without contact between groups. 


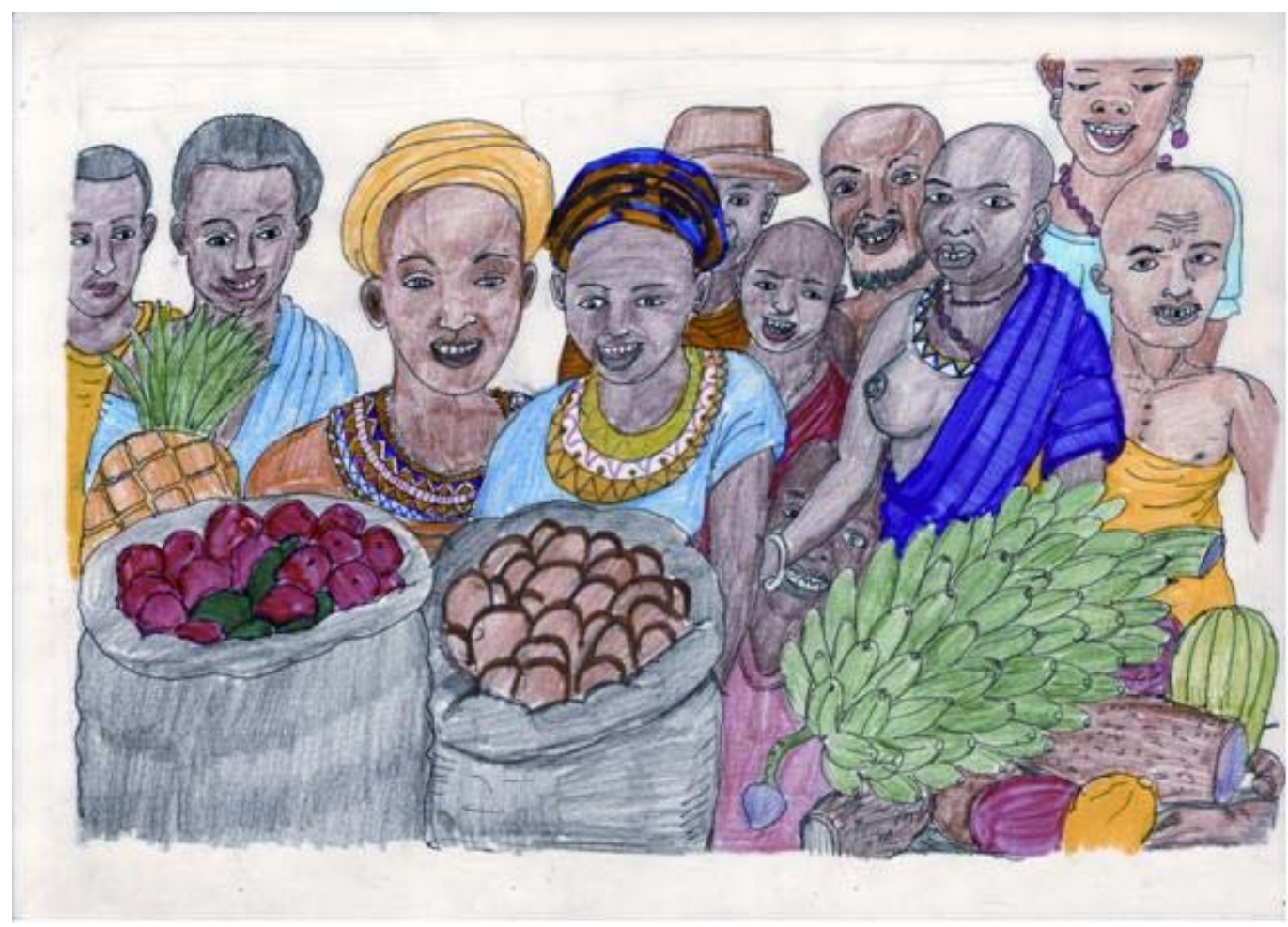

Image 1: Harvest

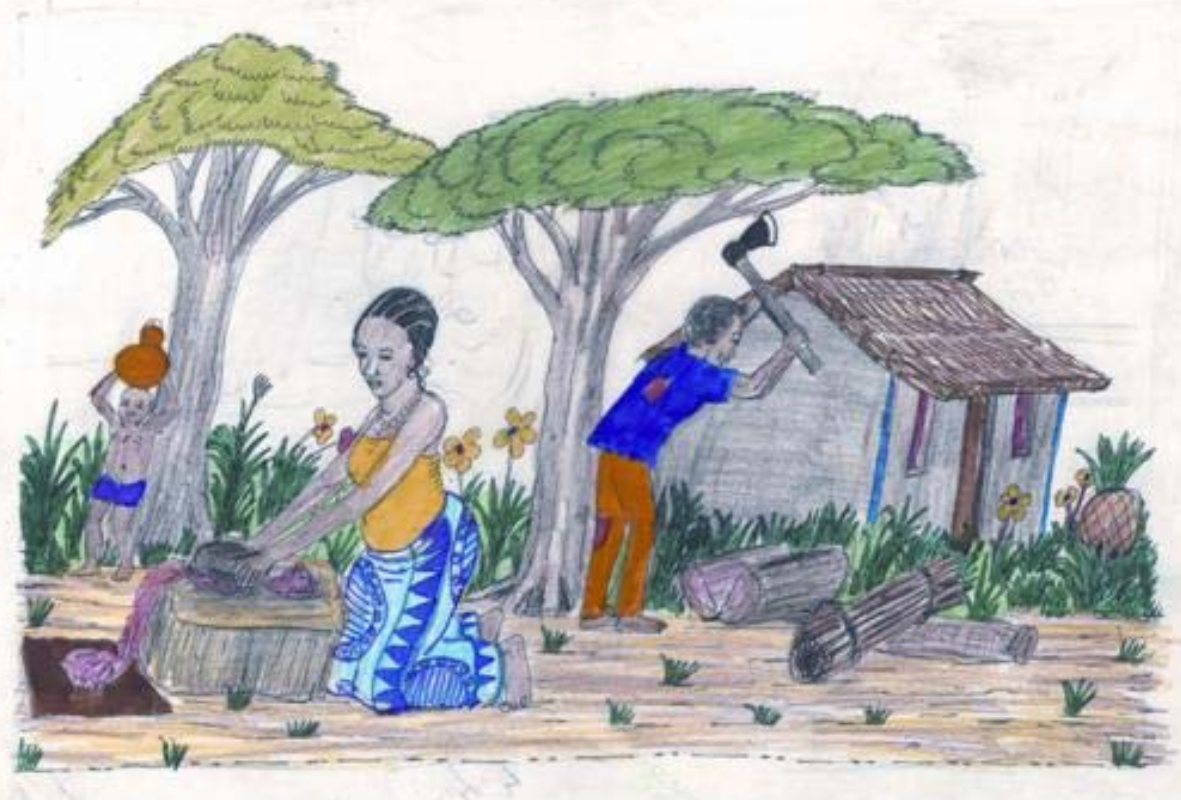

Image 2: Working family 
Looking back, most of the interviewees regard their former lives at home more positively than their current situation. Nevertheless, in their opinion they often had no choice but to leave their homes and come to Mwanza. And only very few would want to go back home. The majority of those who would like to go back do not consider it a realistic option - such as one 13-year old boy:

He says yes, he would like to go back, but according to the situation of there, because the condition of there is bad, and he is going to be in trouble again. ( $8^{\text {th }}$ interview)

Masumbuko describes his village existence very differently. No ideals, instead a representation of great injustice: in both of his pictures men are exerting power over, and violence towards, a boy (the artist). In the picture "Working boy" the boy is sitting on the floor and his task becomes an obligation; the argument that is taking place is reduced to menacing gestures, violence, and power.

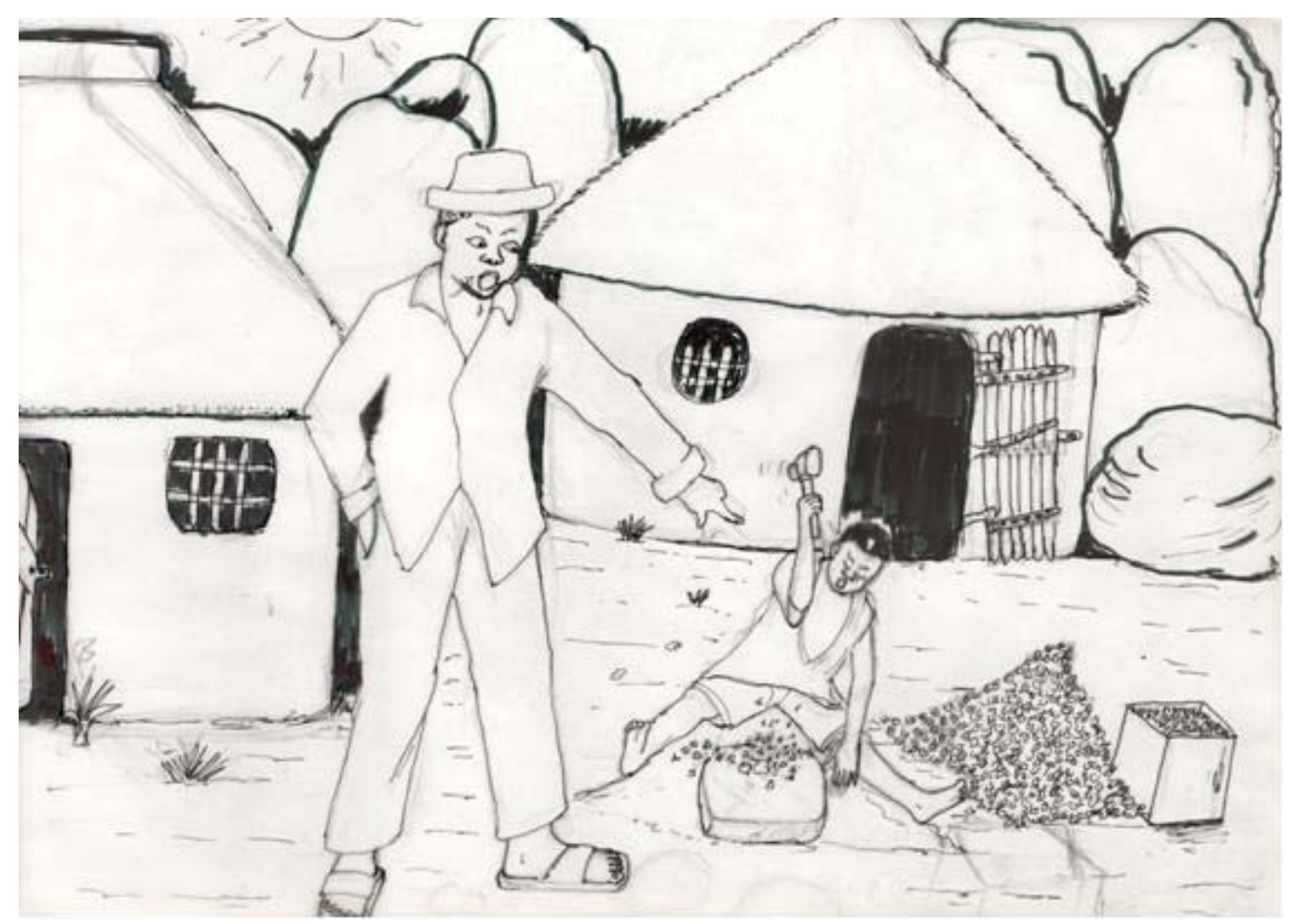

Image 3: Working boy

The picture "Chasing man" illustrates how a man chases a boy with the intent of beating him with a stick. Meanwhile someone is observing the scene from the door without intervening. 


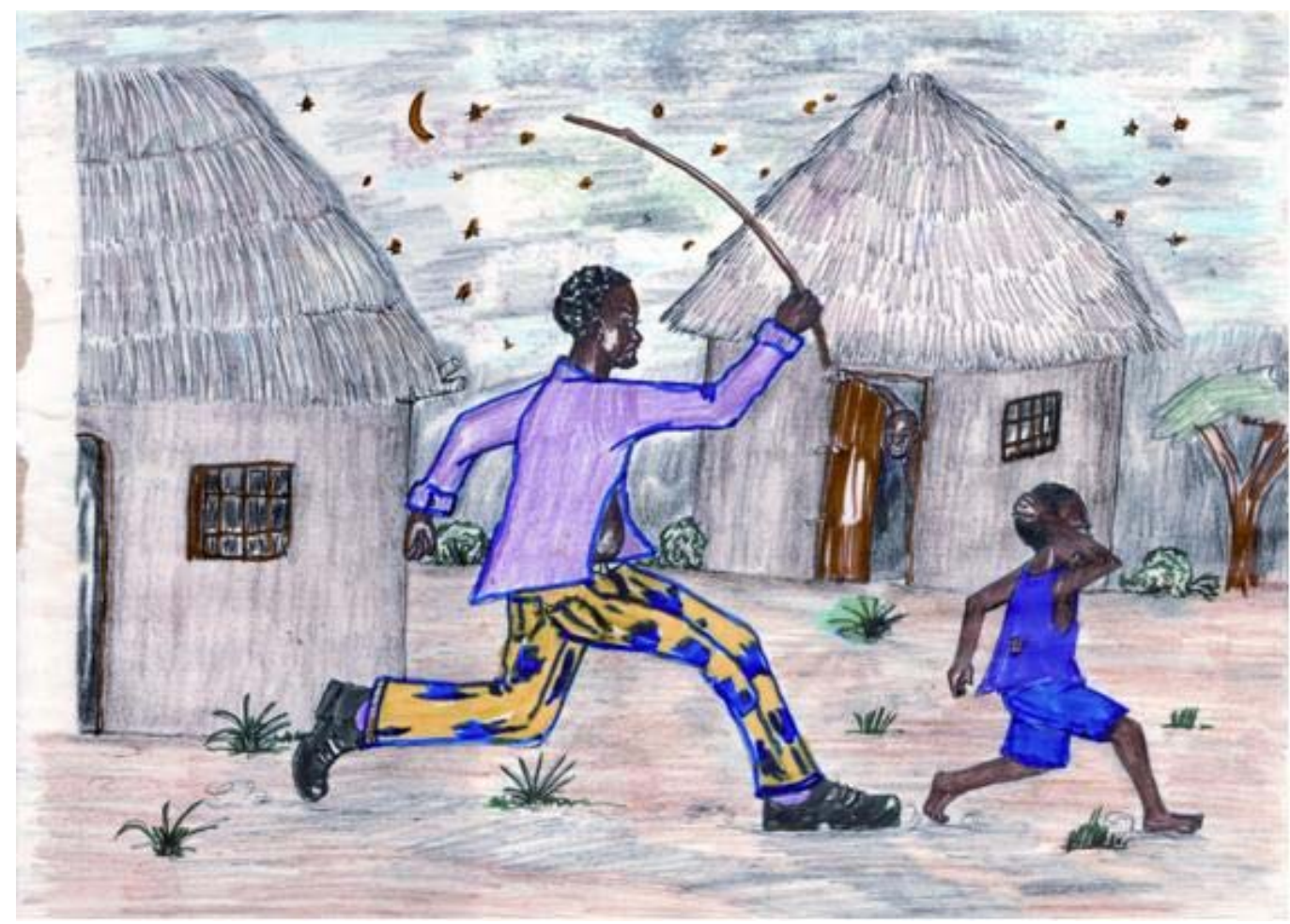

Image 4: Chasing man

The majority of the street children come from rural areas, and only a small percentage of them are from Mwanza itself. The catchment area thus extends from just a few to several hundreds of kilometres away. A typical moment in the biography of a street child is the parents' divorce or the death of one parent followed by the surviving parent remarrying and the stepparent not accepting the child. (Informal studies have shown that most Tanzanian street children come from "broken" homes; Katapa 1998:64.)

So when my stepfather, when my stepfather was drinking, when he came back he used to abuse me that I am not his child [...] And when he hit me $[\ldots]$ (12 $2^{\text {th }}$ interview, 15 -year old male $)$

Or, as in the case of a 16-year old female interviewee, both parents are dead.

They are dead my both parents. So I was living with my grandmother. $\left(21^{\text {st }}\right.$ interview)

Other orphans or half-orphans may no longer have an extended family they can turn to (cf. Nyambedha et al. 2003:1).

\section{(ii) survival strategies}

The picture "Street Kids" gives an impression of the city of Mwanza. Here we are confronted with a situation at a bus station. It concisely represents the life world of street children. In contrast to the village scenes or depictions of children at play, this drawing does not depict rural influences. Instead, we are presented with a busy urban setting with only asphalt, cars, and buildings. At first, the viewer scans the group of children in the foreground. Then with closer observation certain other elements 
become apparent, with each person in their own state of poverty and neglect. Some wear tattered or simple clothes and others are barefoot. A striking consistency in Sengondo's work is the depiction of children as street dwellers. There seems to be no attention given to children with a relatively safe and stable existence.

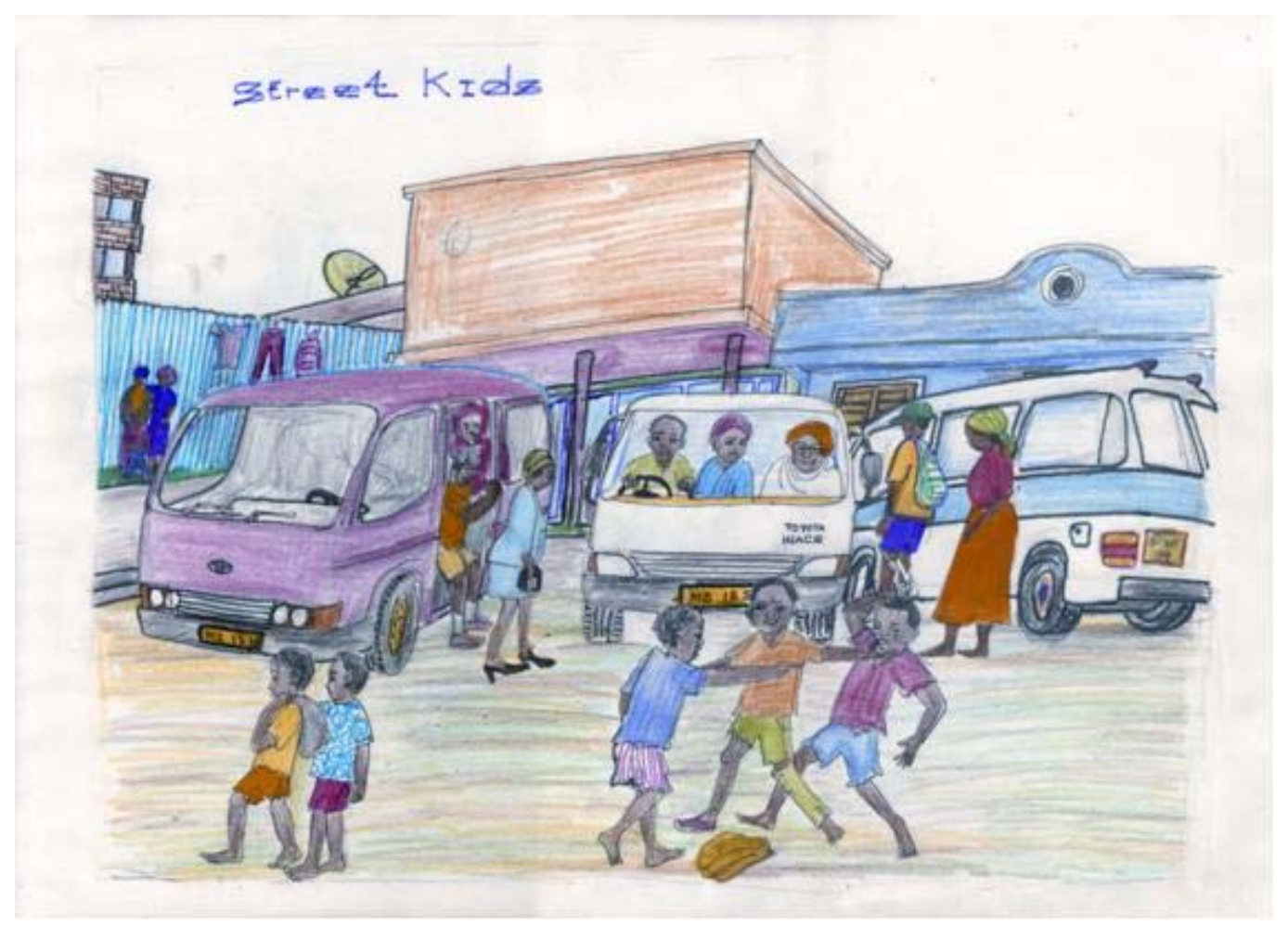

Image 5: Street kids

Amicable relations with children who do not live on the street rarely exist. A 15-year old male interview partner describes an irreconcilable difference here:

Yes, he said, yes I have. But there is a big, big difference because I cannot talk with the child who is living house. He has nothing to help me he said. Because he cannot help me anything, and he cannot take care about my problems. $\left(6^{\text {th }}\right.$ interview $)$

Those street children who get the opportunity to go to school, such as a 19-year old male interviewee, find it easier to make friends of the same age:

He said also I have friends from the community, children, especially others who are studying with me in school. ( $9^{\text {th }}$ interview)

It is noteworthy that none of the female interviewees has a boyfriend who does not live on the street.

In interviews I have been told by both male and female interviewees that most street girls were prostitutes. It was said to be the easiest way of earning money. Schibotto (1993:134) points out that the term "street girl" is used synonymously for "prostitute" in many languages. They are doubly stigmatised: the attempt of aid organisations to reintegrate these girls was foiled by mothers refusing to let their daughters back home, being afraid of AIDS. By my estimation, the likelihood of many girls being infected 
with HIV is very high, though I cannot make predictions concerning the percentage. One thing becomes apparent regarding the street girls and prostitution in Tanzania: those who have contracted HIV cannot be made solely responsible for their illness; they live in complex socio-economic situations where it becomes difficult not to contract the virus (Gronemeyer 2002:156, Haram 2005:8-9).

Street boys perform other work to obtain money or food. Some work in the harbour, loading and unloading ships that mostly bear fish and fruit. Some boys collect pieces of wire to make fishing hooks to sell to the fishermen. Others go fishing and either sell the catch or eat it themselves. Opportunities for work are also offered by the markets in the midst of the city. Here street boys help transport goods to and fro and do cleaning work. They also sell eggs, milk, fruit, cigarettes, sweets or chewing gum. Boys also collect pieces of coal and aluminium rubbish to sell on. Some work in restaurants and bars in town, performing menial tasks and receiving food as payment. It is impossible to walk through Mwanza without being approached by begging street children. Older children are particularly worse off, as they are rarely given anything. When they do receive something, it is probably at the hands of white tourists. A 15year old street boy explains:

He said at the beginning he was very young. And he could go, and on the way they could feel mercy and give him some money, one hundred or two hundred. He said, but now it's hard because he is going to growing up, so he cannot ask money, and they cannot give him because they see he is going to be old. $\left(10^{\text {th }}\right.$ interview)

Another strategy for survival is theft: Sengondo's picture "Harbour theft" shows how a man is robbed by a boy and a girl pulling money out of his pocket. The background shows two cranes, a ship and two cars. Regarding the depicted material wealth, the theft as such seems small and unimportant. The victim seems wealthy, depicted by his tie. Interestingly, both children seem to be working together hand in hand. These three figures appear to form a human chain, unloading the riches from the newly anchored vessel. This demonstrates that children too grasp the influences of globalisation and the economy. 


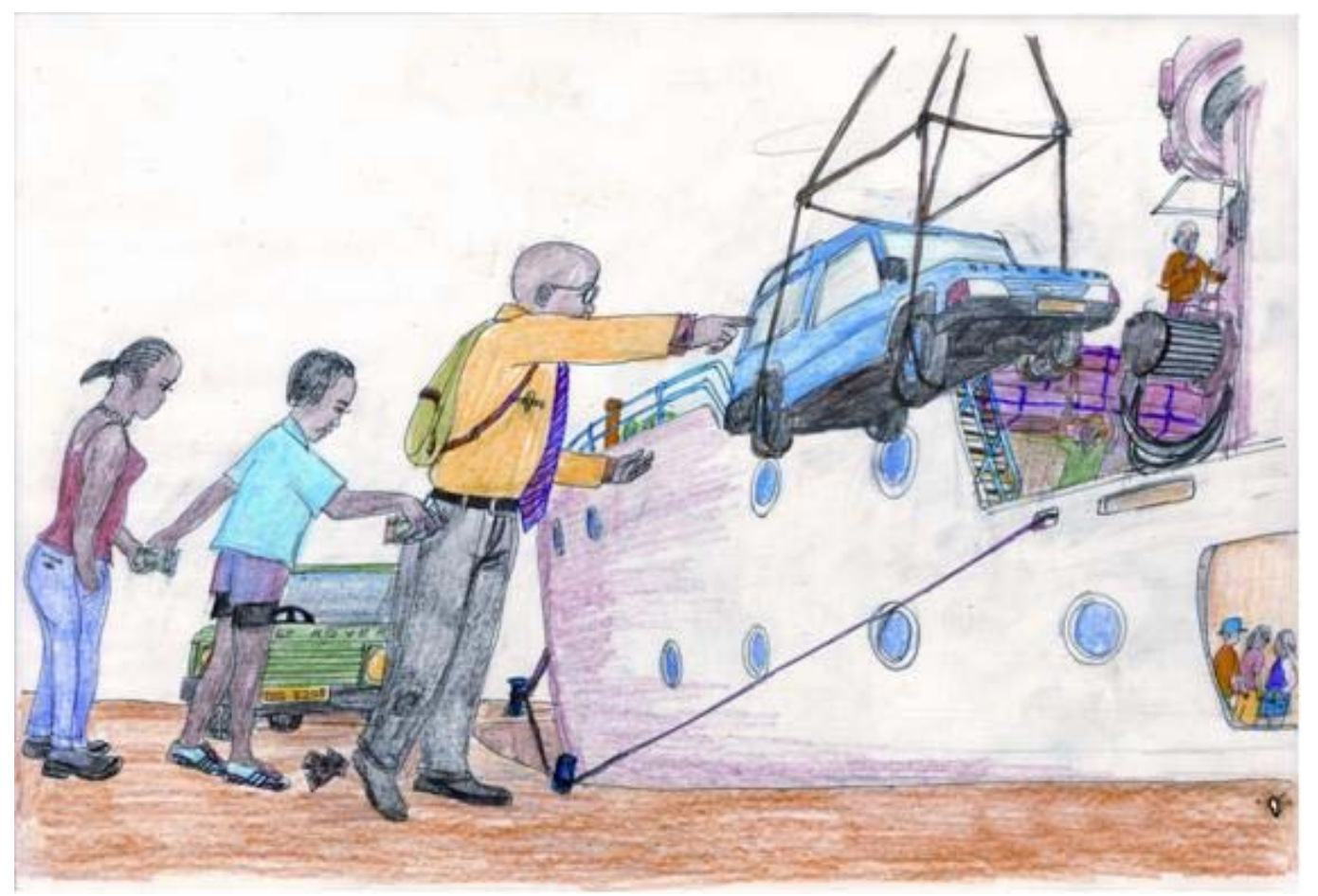

Image 6: Harbour theft

\section{(iii) leisure activities}

In the picture "Glue sniffers", five street boys are holding bottles of glue, while some on the left sniff them. This portrayal of social despair and desperation is reinforced by the background image of a car wreck under a tree. On the right side of the picture, a boy is having an obvious dispute with someone who appears to be a businessman. The man carries a briefcase and a mobile phone attached to his belt. The boy also holds a bottle of glue in his hand. However, unlike his counterparts, he displays a level of resolution, attitude, and presence of mind - sobering characteristics not often attributed to glue-sniffers. The overall impression of community between the gluesniffers only emerges when the compositions are seen together. In the first view, we are left with no signs of solidarity beyond the joint activity of glue-sniffing. Each individual carries this out in their own self-determined way. There is no interaction between them. Yet there seems to be an invisible chain that links the boys on the left in their unspoken support of the boy on the far right. The birds in the background of the picture might represent freedom in contrast to the car which is not going anywhere. This wrecked car keeps the figures optically together, which might be seen also as a connector of separate worlds. And representatives from these contrasting worlds now face each other: the businessman, who might have driven the car when it still functioned, and the societal outsiders who stagnate like broken-down cars. For the viewer the picture thus becomes a hidden metaphor for the street children, who are excluded from society, and for whom, just like car wrecks, there is no room in urban life. 


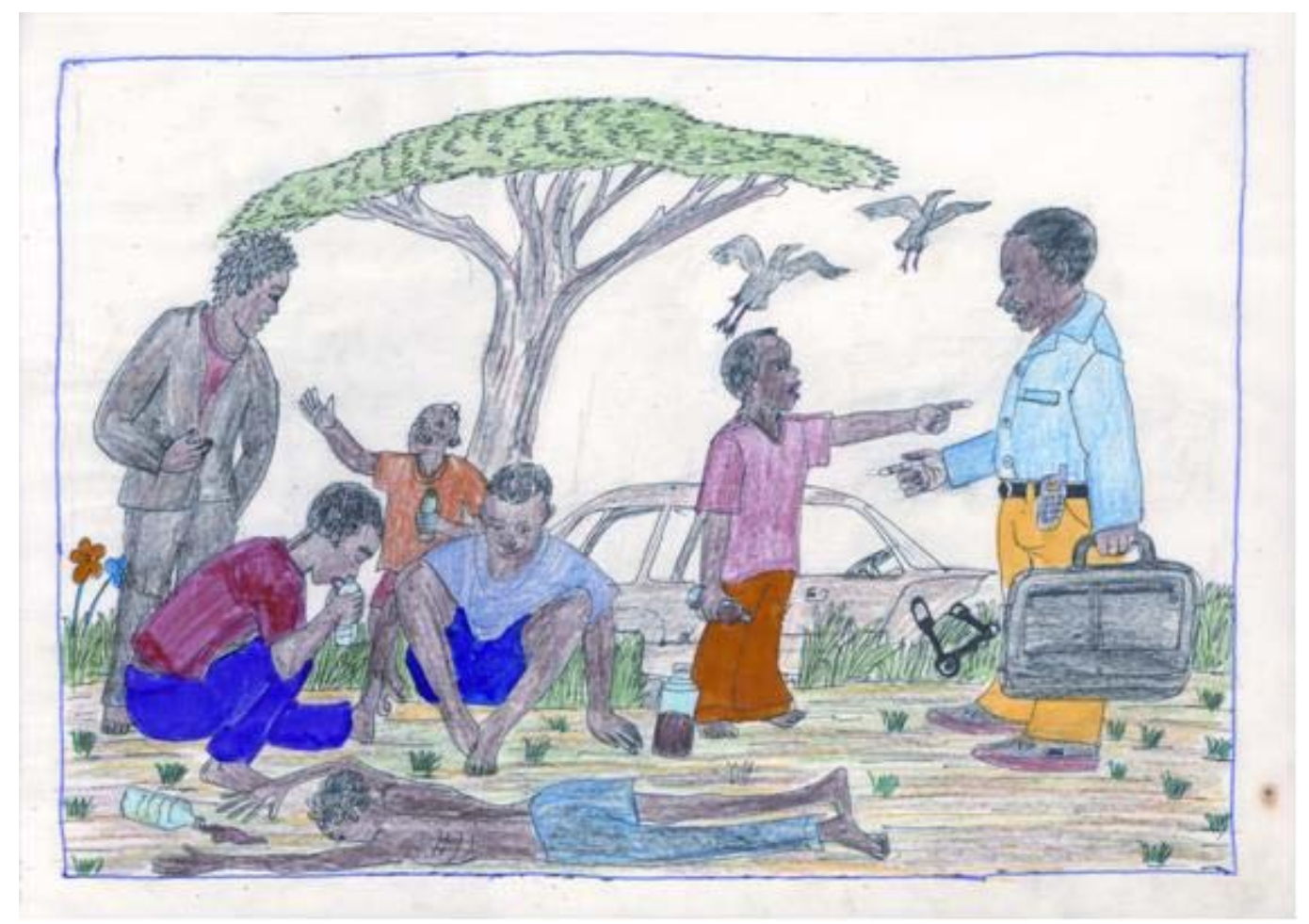

Image 7: Glue sniffers

Recreational drugs play a large role in the life of street children. Street girls particularly smoke cigarettes and drink alcohol, mostly the regional beer called pombe. Boys also smoke cigarettes and drink alcohol, but more commonly turn to smoking marijuana, which numbs both hunger and fears. Solvents are a particular problem amongst the younger children, most of whom abuse these by inhaling the fumes. I have met boys who have abused solvents for longer periods of time and whose voices sounded very hoarse and coated.

\section{(iv) abuse}

The drawing "Escape" depicts a group of six street children who are making a running escape from a storm of dangerous projectiles. They do this by leaping and turning in a somewhat impossible, comic-like fashion towards a body of water (probably Lake Victoria). On the far right, a traditionally dressed woman with a pot of water on her head observes the event. It is unclear who is throwing the stones, axes, knives, and hammer from the left. Some stones have already made contact as one boy is collapsing with a raised arm to protect his head. In his other hand he holds some bank notes while another boy drops bank notes from his pockets - perhaps this is stolen money. What makes this scene particularly strange is the boys' collective decision to find sanctuary in a lake! Then again, when faced with a volley of deadly missiles, even the most inhospitable places can seem like paradise. 


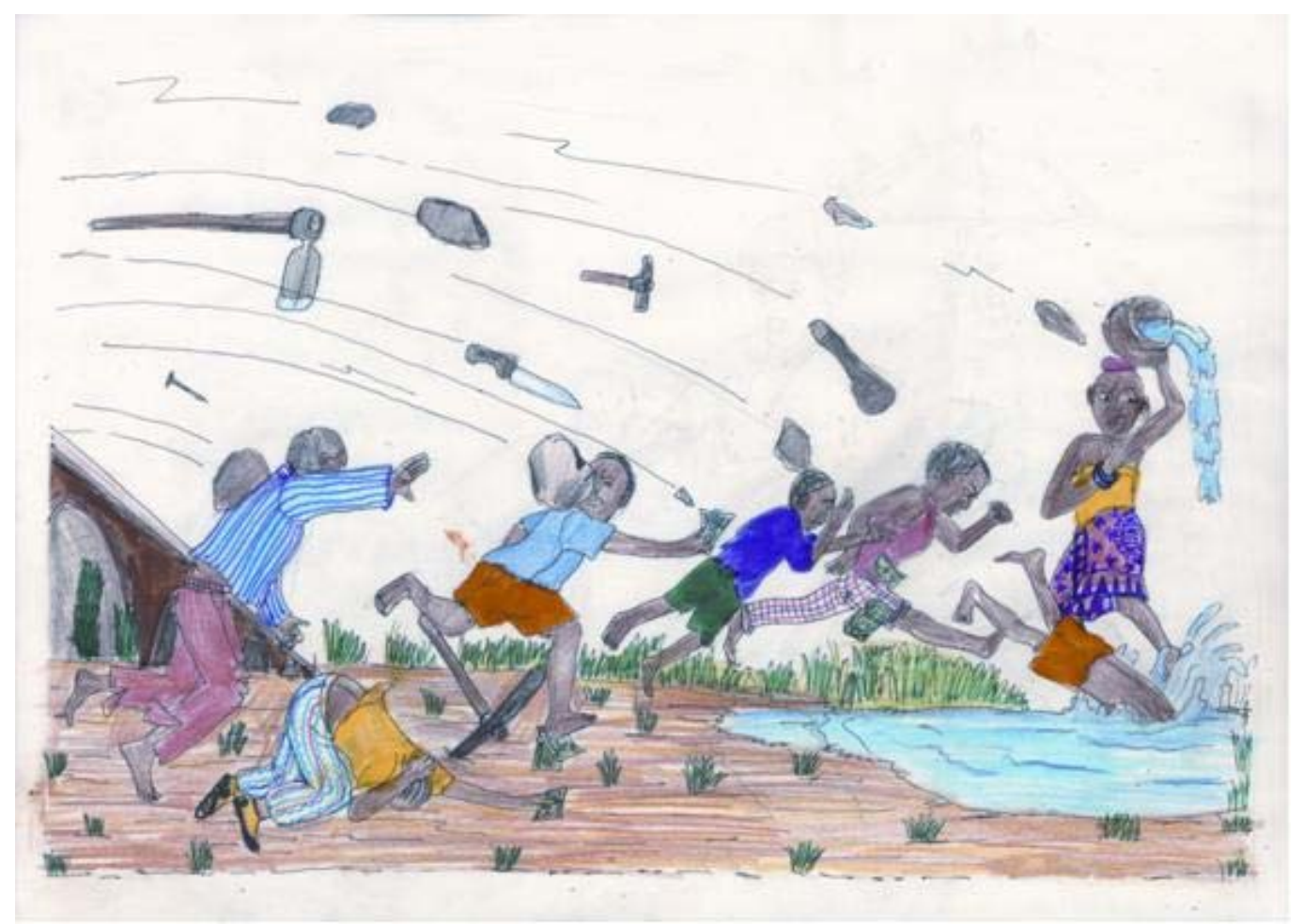

Image 8: Escape

Street children have the reputation of being thieves, are seen as a nuisance, and serve as objects for the projection of others' discontentment and aggressions. In Mwanza they are called watoto wa mitaani, which translates as "children who live on the streets"; a more derogatory term, watoto wa wakoma or "leprous children", is also used (Van Gogh 2000:24). Street children are often insulted by members of the established society. A 19-year old male interviewee also mentions physical violence:

And some people like beating you. And the other children call you a "streetboy" or a "thief" or a "bandit". ( $2^{\text {nd }}$ interview $)$

In the picture below, "Police", we are shown a night-time scene by the lake. A clubwielding policeman is carrying a crying boy by his shorts. In the distance, another policeman seems to be hunting down three additional street children. For Sengondo, the police uniform apparently holds a lot of significance since it is drawn in great detail. Even the emblems and digital watch on the policeman's wrist are clearly illustrated. It almost seems like the boy does not even want to fend off the policeman's violence, for in spite of being threatened by the club, he is still holding his cigarette in his hand instead of using it to defend himself. 


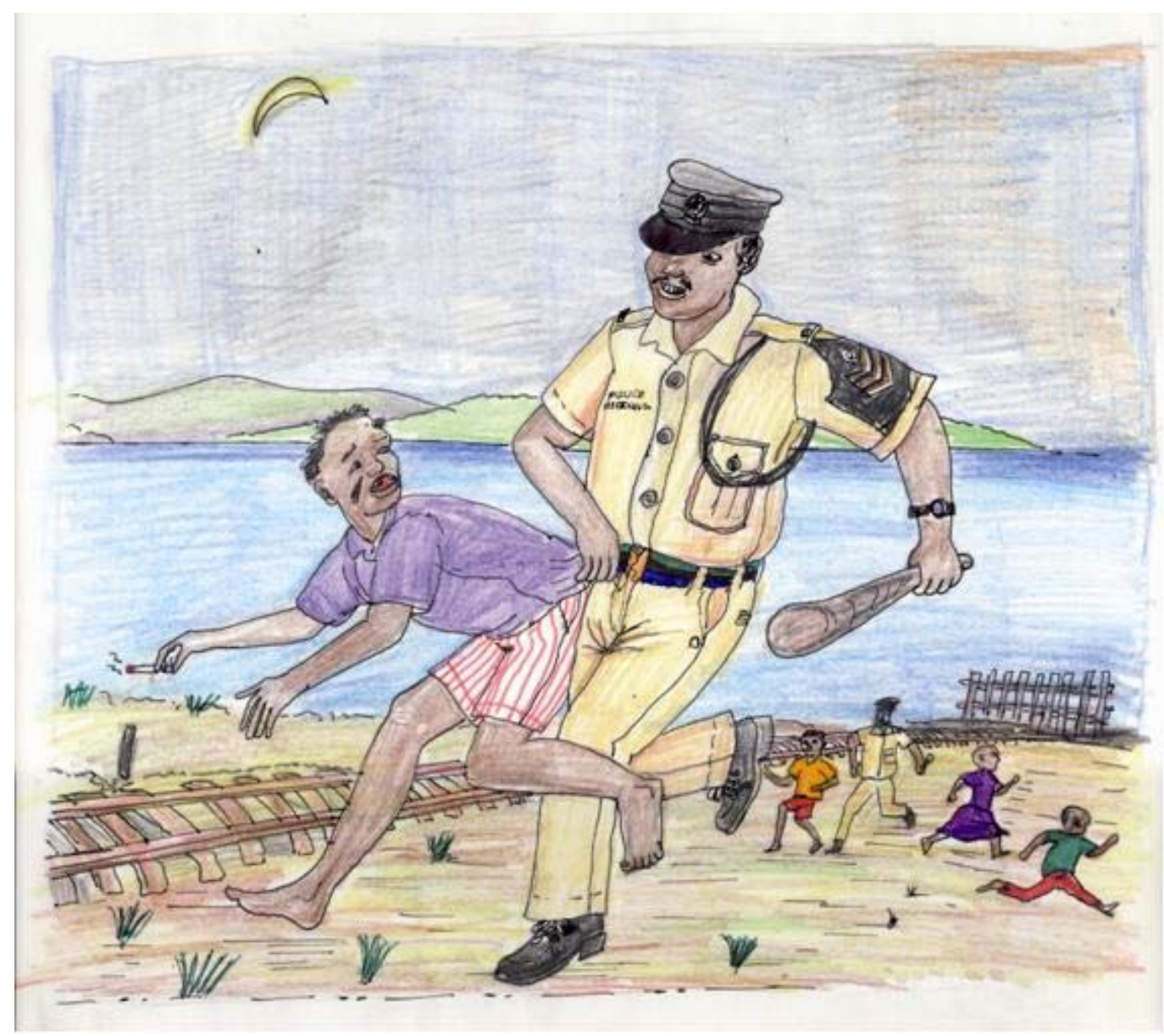

Image 9: Police

The street children are constantly confronted by state violence. When discussing the police, one must differentiate between the state police and private militias. The latter, which are called sungusungu in Kiswahili, are not always officially paid. Although I myself have been unable to observe any use of excessive violence by the police or the sungusungu, the interviews again and again show vehement and concurring reports of such violence. It is said that the police prefer to beat the joints of their victims, as no external bleeding occurs.

A 19-year old male interviewee says:

So the policemen come, always come to beat him, to disturb where you are sleeping. [...] The traditional police and police are altogether, and then they hit street children. If they want to meet you somewhere, they hit when you are sleeping under floor, they just hit you there. $\left(9^{\text {th }}\right.$ interview)

Regarding the traditional police there are also more differentiated statements which, however, do not change in their essential content.

He says ah sungusungu, the traditional police, they fear the group of street children. He says they normally catch you when you are just yourself. $\left(11^{\text {th }}\right.$ interview, 20-year old male)

Girls are subjected to both physical and sexual abuse. 
She says when you have no money to policemen, they just ask you to sex, they make sexual abuse, and when you are not receiving, accepting, they fight you. ( $16^{\text {th }}$ interview, 17-year old female)

An 18-year old female interviewee describes the situation as follows:

She says there are problems of policemen catching you as a girl and be sending you somewhere to do sexual abuse. And then there are many, not one because policemen - I don't know why - they just come many. And then they keep you on secret, and they do some things, such kind of things. And then after this ah because they have done once, she says, they took me there, and they have done so many things, something like that. $\left(20^{\text {th }}\right.$ interview)

\section{Life worlds and space}

Schütz (1974) modified Husserl's (2002) concept of the life world by adding his concept of "everyday reality" (Alltag). The "everyday world" (Alltagswelt) is the reality in which each human being thinks, feels, lives, acts and communicates. This world is given to each one of us and is accepted naturally and without questioning.

Through individual interaction with the material and social world, the life world is created and the individual horizon of experiences is expanded. Experiencing the life world strongly influences the way human beings act (Lave and Wenger 1991). The life world is divided into separate fields of being in which the individual becomes active: locations of leisure, the street, and so on. One needs a certain amount of knowledge in order to be able to become adequately active in these surroundings; without it, disturbances occur which are perceived as anxiety, a threat or a problem. However, the possibility of being able to apply these learnt patterns of action enables participation in the above-mentioned fields of being, thus providing a feeling of individual security. A subjective feeling of meaning, identification and belonging can be obtained by adhering to the rules, norms and values of the particular field. In this case the individual life world is embedded in societies" "life world pattern" (Lebensweltmuster) which constitutes the frame for all individual patterns of thought and interpretation (Dachtler 1999:74-75, Schubert 1994:166-180, Grathoff 1995, Schütz and Luckmann 1979). As described above, street children encounter great difficulties in achieving relevant knowledge and skill in some areas due to a lack of social recognition.

The life world of the street children is inseparable from the urban environment in which they live. When, as a result of globalisation, children and youths migrate to the cities, the spatial organisation of their social relationships change. These processes of change are also reflected in the differences between the village and city pictures. Social relationships always have a spatial form and a spatial content. They necessarily exist within the space (e.g. in a relationship of locality with other social phenomena) as well as transcending its borders. The complexly interwoven and self-articulating networks of social relationships form the social space. As these networks are dynamic, so the social space is also in motion (Massey 1994:168-169). Simmel (1995) has already pointed out that relations between human beings in the city become considerably more impersonal, superficial, transient, and segmented than they are in village life. Due to more individuals being involved in the interaction processes, the degree of possible social differentiation between them increases while at the same time the degree of communication declines (cf. Wirth 1964:83). 
The city brings with it a different moral order in which the position and selfawareness of the street children is defined anew by the attitudes and standards of other individuals and groups. The meaning of their newly prescribed social status is social distance. And social distance stands in close relation to spatial distance, as physical distance is also an index for social distance (Park 1926:17-18). As the fundamental system of spatial divisions like subject and object, inclusion and exclusion, as well as spatial separations such as close and far, present and absent, cultural and natural, space determines social points of reference for perception which in turn generates the hegemonic system of ideology and practice. The spatial preconditions constitute cultural perceptions and prejudices, and establish performative codes which link social practices and ways of social interaction to their respective milieu. In this respect, spatial concepts manifest themselves in societal discourses. They play an important role in justifying and legitimising everyday decisions and actions (cf. Lakoff and Johnson 2003). The spatial separations are also constitutive of social separations between groups (Shields 1991:46-47). In his drawings "Glue sniffers", "Escape" and "Police", Sengondo depicts these social separations between groups very clearly. The street children's urban living environment is thus not ontologically defined at the outset, but first receives its meaning as social space when its residents discursively and physically define it in their everyday lives (De Certeau 1988). When children have to live on the streets they first of all have to learn about how such a context operates. If they achieve this they can then start to manipulate it with practice. As described above in the section "Stories and drawings" they carry out various tasks and adopt certain behavioural patterns, such as glue sniffing, that are associated with street children.

The social space comprises the potential positions which an individual can assume and which form her/his existence. According to Bourdieu (1983) the individual's position is shaped by her/his economic, cultural, social and symbolic capital. The economic capital includes income and property, the cultural capital is gained through education. The social capital is formed by origin, relationships and membership to a group; the symbolic is gained when the three other forms are perceived as legitimate and respected as such. The street children have little cultural and no economic capital, but great ability to develop social capital (cf. Wolf 2004:188). They provide mutual support to each other for surviving on the streets. Sengondo and Masumbuko can also gain social capital through their drawings.

The street children live in their small social life world, in a concrete social space. On the one hand the children contribute to the construction of this space, while on the other hand the structure of the space plays a decisive role in shaping the children. Bourdieu (1977) examined the way in which the structure of social space is translated into physical experience and practice. He proposes his key concept of habitus as a generative and structuring principle of collective strategies and social practices which is used to reproduce existing structures. Through everyday experience of the spatial symbolism of the street, a person embodies the social structure and incorporates it into her/his everyday practices. As the concept of habitus relates social structures spatially to the human body and bodily practices it also includes the possibility of resistance to the social structure (Giroux 1983, Low 1999:114). In the case of the street children this resistance becomes evident e.g. in their survival activities, especially in delinquency - such as depicted by Sengondo in his picture "Harbour theft".

The street children, acting as social actors, create their own realities and meanings within public space. However, as other humans and institutions are involved in the 
social production and construction of the public space, conflicts always occur (cf. Low 1999:112-113). This is because the street children occupy spaces which were not intended for them, and thus they threaten the social order. A 13-year old male interviewee has repeatedly experienced social exclusion:

He says that I always go to the shop owners, and when I ask for some money some they give me and some decline. And the majority of them, they think that I am a thief, and they find some stick to fight me, and I run away, and so I have nowhere to go. ( $8^{\text {th }}$ interview)

However, the lack of cohesion within the social structure poses not only a danger but also a possibility for new social patterns (Douglas 1988). I wish to examine this aspect more closely. The children who come to Mwanza initially stand on a threshold as they turn into street children. They are in a transitional process; they learn how to survive on the streets and to develop the appropriate strategies with which to do so (cf. Lave and Wenger 1991). On the streets the process of identity formation takes place for the children who come to Mwanza and start to live on the street there.

\section{The street as the place of identity formation}

One can comprehend the life world of the street children as a system of closed selfreferences in Luhmann's sense. "The term 'self-reference' describes a unity which is an element, a process, a system in itself. 'In itself' - that means: independent of alteration through the observation of others" (Luhmann 1987:58). This does not stand in contradiction to the system being open to the surrounding environment. "The unity of the self-referential operational method is far more a form of expansion of possible contacts with the outside world; through constituting better definable elements, the complexity possible for the system is increased" (ibid:63). The system's relation to its environment is constitutive for the formation of the system. It is the precondition for the identity of the "street children" system, as identity is only possible through difference (ibid:63, 242-243).

In the interviews and in general, my informants described themselves as "street children" and as being separate from society. Clear commonalities exist despite individual differences, meaning that a system in Luhmann's sense is created. The survival strategies and everyday life reality reveal strong similarities amongst all the children. All are exposed to similar dangers and threats. The torn and dirty clothing, the permanent residency on the street, the rough tones of voice and the sleeping outdoors: to an outsider, this all points to affiliation with the culture of the street children. Other members of society generally distance themselves from them and associate them with theft in particular and any menace in general. This conversely causes the street children to feel they do not belong to society, that they are different. The age structure lies between 13 and 20 years old, with a scattering of younger ones from seven onwards and older ones of up to 22 years of age. Important internal information is passed on with high rapidity, like the cinema scheduling, police crackdowns, arrests, or opportunities to obtain money. Through their participation in the system, the children receive protection and safety. Thus arrested children are provided with sustenance, food and money that is shared to some extent, and other children are protected against violence from members of society. The street children are very strongly socialised at a young age by the other street children. New arrivals meet with hardened social structures and behavioural patterns that are assimilated. The construction processes of the identity of the street children can be viewed as a 
collective process of the separation of their social group from other social groups (cf. Seebode 2003:200).

In psychology, "identity" describes the image that a person has of herself/himself (Zaumseil 1997:148). In this respect, identity is constructed by a person herself/himself, and information regarding her/his identity may only be obtained from the person herself/himself. Identity has to be distinguished both from role, the complex of societal expectations regarding the individual's behaviour within her/his life world, and from personality, the total of all psychological features of a person. For as a self-construction, identity exists, as opposed to role and personality, within the individual's consciousness, and accordingly it must be investigated there. At the same time, identity is a relational notion that provides information e.g. on how a person is now compared to the past, or here compared to there (Haußer 1995:3-4). In sociology, however, identity is the image that a person ascribes to and has been ascribed, i.e. the person's role or social identity in the public social space (cf. Goffman 2004). The two concepts belong together, as a person can only form an image of herself/himself on the basis of her/his culture and through interaction with others (Zaumseil 1997:148). The individual develops her/his identity in the course of her/his interaction with the social environment (cf. Leferink 1997). As the identity structures can also change, it makes sense to describe identity as a continuing process of construction, within which a person interacts with others (Bruner 1990).

On the streets, the children come together through their participation in street life, and the shared experiences and the resulting trust form social networks, within which they receive social support. According to Röhrle (1994), these social networks are defined as "the total of social relationships between a defined amount of people, roles or organisations" (ibid:1). Social networks have identity-forming functions and can generate a stable, positive feeling of self-worth (Heller, Swindle and Dusenbury 1986). Within the group of street children learning processes take place, which are more or less successful (cf. Röhrle 1994). Social support can influence the individual mind state. The elimination of stress factors can be viewed as a socially interactive occurrence (cf. Albrecht and Adelman 1987). The process of eliminating stress factors may be supported not only by encouragement and motivation but also by collective acting (cf. Wiencke 2006, 2007b).

\section{Discrimination and stigmatisation}

The unequally distributed life chances among Mwanza's inhabitants correspond to the unequal distribution of societal acceptance. Together with societal acceptance a social status is attributed to the social actor which determines her/his rights and obligations. Status systems may be investigated as networks of asymmetric social relations, which are structured by means of the acting of individuals and groups. The collective of street children can be considered a status group since all street children have similar resources, which are associated with a common social prestige (Neckel 1991:193197).

Here, I do not mean individual prejudices when I speak of stigmatisation, but always the stigmatisation of the whole group of street children. The key to this problem of social prejudice lies in the pattern of interdependence between the group of street children and other groups in society. Its crux can be found in the imbalance of power and in the resulting tensions. Through the unequal division of power, the groups in the 
established society can stigmatise the street children group and thus claim their own social superiority (Elias and Scotson 2000:14).

A stigma is a broad and multidimensional construct which is based on the concept of deviation from an ideal or an expectation. According to Goffman (2004:100), it is principally a powerful discrediting social label which radically alters the way in which people perceive themselves and are perceived by others. People who do not meet the normative expectations on account of having different or unwanted attributes, are not accepted and are belittled. The discrepancy between the socially desirable attributes and those which the people possess damage their social identity and isolate them from societal acceptance. The term "stigma" is used in a language of relations. Wittgenstein (1984) writes that words are not maps of reality, but receive their meaning through their use in social exchanges, in the language games of each culture. In this respect, a given stigmatising attribute is not in itself pathological, immoral or deviant; instead it only first becomes so through culturally embedded meanings, i.e. through a specific historical and cultural context.

Stigmas create outsiders whose chances in life are thus reduced. Street children are in this sense stigmatised, marginalised and discriminated against. Many studies of street children in different societies show that the biggest fear amongst the children is the enmity of the public and the police (Aptekar and Abebe 1997:477). The reigning discriminatory attitude distorts others' perceptions of the street children and ruins their chances. This attitude is the basis and justification for manifold forms of abuse.

\section{Conclusion}

In 2004, my translator from 2001 attempted to re-question my interview partners. Of the original 22 interview partners, 14 could no longer be found. Six male interviewees had emigrated to another city, one had found a job, one was in prison, and another one was in the new centre of an aid project. Of the unavailable female informants, one had died of AIDS, two continued to live on the street in Mwanza, and another two had gone to Dar es Salaam. The re-interviewed persons gave differing statements on the developments over the three years. For some the situation had greatly improved. Thus one male and one female informant worked with an aid project. Two female and four male interview partners continued to live on the street, and one male interviewee was in prison.

In my opinion, the crucial point for enhancing their life situation can be found in the relationship between the street children and society. This is because the position of the actors within the social structures of power determines to what extent they gain access to the common, shared culture of a society (Seebode 2003:201). The street children of Mwanza are social actors, who, in Bourdieu's (1983) terms, accumulate social capital that helps them to orient themselves in their lives. Instead of depicting street children as vulnerable victims (as is often done in the media and the advertising of aid organisations), it is crucial to illustrate the fields in which they act and the way in which these are positively used. The concept of social capital offers a new perspective on their vulnerability. If the street children's capacities to cope with the difficulties occurring in their everyday life were more widely recognised, they would achieve more social acceptance and thus also accrue symbolic capital. If, however, they are considered to be victims, a negative prognosis regarding their present and future 
behaviour will be made. However, they actively determine their own position within societal space, e.g. by creating networks and mutually supporting each other.

\section{References}

Alber, Erdmute. 2003. Kindheit [Childhood]. In Das kleine Afrika-Lexikon [The small Africa lexicon] (ed.) Jacob Emmanuel Mabe, 91-92. Stuttgart: Metzler.

Albrecht, Terrance L. and Adelman, Mara B. 1987. Communicating social support: a theoretical perspective. In Communicating social support (eds.) Terrance L. Albrecht and Mara B. Adelman, 18-39. Beverly Hills: Sage.

Aptekar, Lewis and Behailu Abebe. 1997. Conflict in the neighbourhood: Street and working children in the public space. The International Journal of Children's Rights 5 (4), 477- 490.

Belo, Jane. 1970. Balinese children's drawing. In Traditional Balinese culture (ed.) Jane Belo, 240-259. New York: Columbia University Press.

Bourdieu, Pierre. 1977. Outline of a theory of practice. Cambridge: Cambridge University Press.

--------. 1983. Ökonomisches Kapital, kulturelles Kapital, soziales Kapital [Economic capital, cultural capital, social capital]. In Soziale Ungleichheiten [Social inequalities] (ed.) Reinhard Kreckel, 183-198. Göttingen: Nomos.

Bruner, Jerome S. 1990. Acts of meaning. Cambridge: Harvard University Press.

Dachtler, Armin. 1999. Die Straßenkinder in Tansania: Darstellung ihrer Lebenswelt am Beispiel der Stadt Bukoba. [Street children in Tanzania: Depictions of their life world using the example of the city of Bukoba]. Frankfurt a. M.: IKO.

De Certeau, Michel. 1988. The practice of everyday life. Berkeley, Los Angeles: University of California Press.

Denzin, Norman K. 1989. The research act $\left(3^{\text {rd }}\right.$ ed.). Englewod Cliffs, NJ: Prentice Hall.

Donald, David and Jill Swart-Kruger. 1994. The South African street child: Developmental implications. South African Journal of Psychology 24(4), 169174.

Geertz, C. (1999). Dichte Beschreibung: Beiträge zum Verstehen kultureller Systeme. [Thick description: Toward an interpretive theory of culture]. Frankfurt a. M.: Suhrkamp.

Giroux, Henry A. 1983. Theories of reproduction and resistance in the new sociology of education: Critical analysis. Harvard Educational Review 33, 257-293.

Glauser, Benno. 1997. Street children: Deconstructing a construct. In Constructing and reconstructing childhood: Contemporary issues in the sociological study of childhood, $2^{\text {nd }}$ ed. (eds.) Allison James and Alan Prout, 145-164. London: Falmer Press.

Goffman, Erving. 2004. Stigma: Über Techniken der Bewältigung beschädigter Identität. [Stigma: Notes on the management of spoiled identity]. Frankfurt a. M.: Suhrkamp. 
Grathoff, Richard. 1995. Milieu und Lebenswelt: Einführung in die phänomenologische Soziologie und die sozial-phänomenologische Forschung. [Setting and life world: An introduction to phenomenological sociology and social phenomenological research]. Frankfurt a. M.: Suhrkamp.

Gronemeyer, Reimer. 2002. So stirbt man in Afrika an AIDS: Warum westliche Gesundheitskonzepte im südlichen Afrika scheitern. [Dying of AIDS in Africa: Why Western health concepts fail in Southern Africa]. Frankfurt a. M.: Brandes and Apsel.

Haram, Liv. 2005. AIDS and risk: The handling of uncertainty in northern Tanzania. Culture, Health and Sexuality 7(1), 1-11.

Heller, Kenneth, Ralph W. Swindle and Linda Dusenbury. 1986. Component social support processes: Comments and integration. Journal of Consulting and Clinical Psychology 54, 466-470.

Honig, Michael-Sebastian, Hans Rudolf Leu and Ursula Nissen. 1996. Kinder und Kindheit: Soziokulturelle Muster - sozialisationstheoretische Perspektiven. [Children and childhood: Socio-cultural patterns - socialisation-theoretical perspectives]. Weinheim, Munich: Juventa.

Husserl, Edmund. 2002. Das Problem der Lebenswelt [The problem of the life world]. In Edmund Husserl: Phänomenologie der Lebenswelt. Ausgewählte Texte II [Edmund Husserl: Phenomenology of the life world. Selected texts II] (ed.) Klaus Held, 220-292. Stuttgart: Reclam.

James, Allison and Alan Prout. 1997. A new paradigm for the sociology of childhood? Provenance, promise and problems. In Constructing and reconstructing childhood: Contemporary issues in the sociological study of childhood (eds.) Allison James and Alan Prout, 7-34. London, New York, Philadelphia: The Falmer Press.

Katapa, Rosalia S. 1998. Nyakusa teenage sexuality - past and present. In Haraka, Haraka... Look before you leap: Youth at the crossroad of custom and modernity (eds.) Magdalena K. Rwebangira and Rita Liljeström, 43-68. Stockholm: Elanders Gotab.

Lakoff, George and Mark Johnson. 2003. Metaphors we live by. Chicago: University of Chicago Press.

Lave, Jean and Etienne Wenger. 1991. Situated learning: Legitimate peripheral participation. Cambridge: Cambridge University Press.

Liebel, Manfred. 1993. Vorwort [Preface]. In Unsichtbare Kindheit: Kinder in der informellen Ökonomie [Invisible childhood: Children within the informal economy] (ed.) Giangi Schibotto, 10-14, Frankfurt a. M.: IKO.

Low, Setha M. 1999. Spatializing culture: The social production and social construction of public space in Costa Rica. In Theorizing the city: The new urban anthropology reader (ed.) Setha M. Low, 111-137. New Brunswick, London: Rutgers University Press.

Luhmann, Niklas. 1987. Soziale Systeme: Grundriss einer allgemeinen Theorie. [Social systems: Outline of a general theory]. Frankfurt a. M.: Suhrkamp. 
Luig, Ute and Jochen Seebode. 2003. Einleitung. Ethnologie der Jugend: Soziale Praxis, moralische Diskurse und inszenierte Körperlichkeit [Introduction. Anthropology of youth: Social practices, moral discourses and representation of the body]. In Ethnologie der Jugend: Soziale Praxis, moralische Diskurse und inszenierte Körperlichkeit [Anthropology of youth: Social practices, moral discourses and representation of the body] (eds.) Ute Luig and Jochen Seebode, 9-40. Münster: LIT.

. 2007. Vorwort [Preface]. In Straßenkinder in Tansania: Ihre Lebenswelt in der Stadt Mwanza [Street children in Tanzania: Their life world in the city of Mwanza] (ed.) Markus Wiencke, 7-8. Frankfurt a. M., London: IKO.

Massey, Doreen. 1994. A place called home. In Space, place and gender (ed.) Doreen Massey, 157-173. Cambridge: Polity Press.

Matt, Eduard. 2003. Darstellung qualitativer Forschung [Presentation of qualitative research]. In Qualitative Forschung - ein Handbuch [Qualitative research - A manual], $2^{\text {nd }}$ ed. (eds.) Uwe Flick, Ernst von Kardorff and Ines Steinke, 578587. Reinbek: Rowohlt.

Mayring, Philipp. 2003. Qualitative Inhaltsanalyse [Qualitative content analysis]. In Qualitative Forschung - ein Handbuch [Qualitative research $-A$ manual], $2^{\text {nd }}$ ed. (eds.) Uwe Flick, Ernst von Kardorff and Ines Steinke, 468-475. Reinbek: Rowohlt.

Neckel, Sighard. 1991. Status und Scham: Zur symbolischen Reproduktion sozialer Ungleichheit. [Status and shame: On symbolic reproduction of social inequality]. Frankfurt a. M.: Campus.

Nyambedha, Erick O., Simiyu Wandibba and Jens Aagaard-Hansen. 2003. Changing patterns of orphan care due to the HIV epidemic in western Kenya. Social Science and Medicine 57, 301-311.

Park, Robert E. 1926. The urban community as a spatial pattern and a moral order. In The urban community (ed.) Ernest W. Burgess, 3-18. Chicago: Chicago University Press.

Richter, Linda M. 1988. Street children: The nature and scope of the problem in Southern Africa. The Child Care Worker 6, 11-14.

Röhrle, Bernd. 1994. Soziale Netzwerke und soziale Unterstützung [Social networks and social support]. Weinheim: Beltz.

Scheper-Hughes, Nancy and Daniel Hoffman. 1998. Brazilian apartheid: Street kids and the struggle for urban space. In Small wars: The cultural politics of childhood (eds.) Nancy Scheper-Hughes and Carolyn Sargent, 352-388. Berkeley: University of California Press.

Schibotto, Giangi. 1993. Unsichtbare Kindheit: Kinder in der informellen Ökonomie [Invisible childhood: Children within the informal economy]. Frankfurt a. M.: IKO.

Schubert, Franz-Christian. 1994. Lebensweltorientierte Sozialarbeit: Grundpostulate, Selbstverständnis und Handlungsperspektiven [Lifeworld-oriented social work: Basic assumptions, self-conception and perspectives on action]. In Professionelle Identitäten in der Sozialarbeit/ Sozialpädagogik: Anstöße, Herausforderungen und Rahmenbedingungen im Prozess der Entwicklung 
eines beruflichen Selbstverständnisses [Professional identities within social work/social pedagogy: Ideas, challenges and basic conditions in the process of developing a professional self-conception] (ed.) Wilhelm Klüsche, 165-211. Mönchengladbach: Fachhochschule Niederrhein [University of Applied Science of Niederrhein], Fachbereich Sozialwesen [Social Studies Department].

Schütz, Alfred. 1974. Der sinnhafte Aufbau der sozialen Welt: Eine Einleitung in die verstehende Soziologie [The phenomenology of the social world: An introduction to interpretative sociology]. Frankfurt a. M.: Suhrkamp.

Schütz, Alfred and Thomas Luckmann. 1979. Strukturen der Lebenswelt [Structures of the life world], vols. 1 and 2. Frankfurt a. M.: Suhrkamp.

Seebode, Jochen. 2003. Tanzwettkämpfe, Transformationsprozesse und Identität: Tanzstile junger Männer in Nordmalawi [Dance competitions, transformation processes and identity: Dance styles of young men in Northern Malawi]. In Ethnologie der Jugend: Soziale Praxis, moralische Diskurse und inszenierte Körperlichkeit [Anthropology of youth: Social practices, moral discourses and representation of the body] (eds.) Ute Luig and Jochen Seebode, 199-239. Münster: LIT.

Shields, Rob. 1991. Alternative geographies of modernity. In Places on the margin: Alternative geographies of modernity (ed.) Rob Shields, 29-70. London, New York: Routledge.

Simmel, Georg. 1995. Die Großstadt und das Geistesleben [The metropolis and mental life], vol. 7 of complete works, 116-131. Frankfurt a. M.: Suhrkamp.

Spradley, James P. 1979. The ethnographic interview. New York: Holt, Rinehart and Winston.

1980. Participant observation. New York: Holt, Rinehart and Winston.

Van Gogh, Martijn. 2000. Street youth of Mwanza: Survival and coping strategies. Centre for International Development Issues, Catholic University of Nijmegen: Thesis, unpublished manuscript.

Wiencke, Markus. 2006. Schizophrenie als Ergebnis von Wechselwirkungen: Georg Simmels Individualitätskonzept in der Klinischen Psychologie [Schizophrenia in Wechselwirkungen: Georg Simmel's concept of individuality in clinical psychology]. In Georg Simmel in translation: Interdisciplinary bordercrossings in culture and modernity (ed.) David D. Kim, 123-155. Newcastle: Cambridge Scholars Press.

2007a. Straßenkinder in Tansania: Ihre Lebenswelt in der Stadt Mwanza. [Street children in Tanzania: Their life world in the city of Mwanza]. Frankfurt a. M., London: IKO.

--------. 2007b. Wahnsinn als Besessenheit: Der Umgang mit psychisch Kranken in spiritistischen Zentren in Brasilien [Madness as possession: Dealing with mentally ill people in spiritistic centres in Brazil], $2^{\text {nd }}$ rev. ed. Frankfurt a. M., London: IKO.

Wirth, Louis. 1964. Urbanism as a way of life. In Louis Wirth on cities and social life: Selected papers (ed.) Albert J. Reiss, 60-83. Chicago: Chicago University Press. 
Wittgenstein, Ludwig. 1984. Philosophische Untersuchungen. In Werkausgabe Band 1 [Philosophical investigations. Complete Works, Vol. 1]. Frankfurt a. M.: Suhrkamp.

Witzel, Andreas. 1989. Das problemzentrierte Interview [The problem-centred interview]. In Qualitative Sozialforschung in der Psychologie [Qualitative social research in psychology], $2^{\text {nd }}$ ed. (ed.) Gerd Jüttemann, 227-255. Weinheim: Beltz.

Wolf, Angelika. 2004. Kinderhaushalte als Folge der Aidsepidemie im südlichen Afrika [Households run by children as a consequence of the AIDS epidemic in Southern Africa]. In Moderne und postkoloniale Transformation: Ethnologische Schrift zum 60. Geburtstag von Ute Luig [Modernity and postcolonial transformation: Ethnological publication in honour of Ute Luig's $60^{\text {th }}$ birthday] (eds.) Hansjörg Dilger, Angelika Wolf, Urte Undine Frömming and Kerstin Volker-Saad, 177-192. Berlin: Weißensee.

Wolff, Stephan. 2003. Wege ins Feld und ihre Varianten [Paths into the field and their variants]. In Qualitative Forschung - ein Handbuch [Qualitative research - A manual], $2^{\text {nd }}$ ed. (eds.) Uwe Flick, Ernst von Kardorff and Ines Steinke, 475485. Reinbek: Rowohlt.

Zaumseil, Manfred. 1997. Modernisierung der Identität von psychisch Kranken? [Modernising the identity of the mentally ill?] In Schizophrenie in der Moderne - Modernisierung der Schizophrenie: Lebensalltag, Identität und soziale Beziehungen von psychisch Kranken in der Großstadt [Schizophrenia and modernity - The modernisation of schizophrenia: Everyday life, identity and social relationships of mentally ill persons in an urban environment] (eds.) Manfred Zaumseil and Klaus Leferink, 145-200. Bonn: PsychiatrieVerlag.

\section{Acknowledgements}

The research that forms the basis for this article was supported by the Department of Ethnology at the Free University of Berlin, Germany. The article itself is a summarised and slightly revised version of material that has previously been published in a book. I am especially grateful to my German publisher IKO-Verlag für Interkulturelle Kommunikation (Frankfurt am Main, London) for giving permission to use parts of my book: Straßenkinder in Tansania: Ihre Lebenswelt in der Stadt Mwanza, 2007. The sections cited from the IKO book appear on the following pages: $12-17,19,21-23,25-29,33-34,45-46,52-54,57-58,61-64,73-74,76,78,108-114$, $116-117,120-123,125-128,131-133,147-149,152-155,157,161-163,165,167-168$. Furthermore I would like to thank Ingie Hovland and two anonymous reviewers for their helpful comments.

\section{About the author}

Markus Wiencke has a degree in psychology and a magister artium in social anthropology. He is a doctoral student at the Free University in Berlin, Germany. His current research focuses on the correlations between sociocentric settings and meaning-making for the treatment of mental illnesses. He has published two books, entitled Straßenkinder in Tansania: Ihre Lebenswelt in der Stadt Mwanza [Street 
children in Tanzania: Their life world in the city of Mwanza], and Wahnsinn als Besessenheit: Der Umgang mit psychisch Kranken in spiritistischen Zentren in Brasilien [Madness as possession: Dealing with mentally ill people in spiritistic centres in Brazil]. He can be contacted at markuswiencke@gmx.de or www.markuswiencke.com. 